\title{
Primary and secondary syphilis, 20 years' experience. 2. Clinical features
}

\author{
A MINDEL, S J TOVEY, D J TIMMINS, P WILLIAMS \\ From the Academic Department of Genitourinary Medicine, University College and Middlesex School of \\ Medicine, London
}

SUMMARY The notes of 946 patients with primary and 854 with secondary syphilis were retrospectively reviewed. Of the 184 heterosexual men with primary syphilis, $182(99 \%)$ had chancres affecting the penis, compared with $467(64 \%)$ of the 728 homosexual men $(p<0.0001)$. Anorectal chancres occurred in $249(34 \%)$ of homosexual men. The commonest features of secondary syphilis included a rash, lymphadenopathy, and mucous patches of the mouth or genital area. Hepatitis, meningitis, other neurological problems, iridocyclitis, and periostitis were all exceptionally rare. The clinical features of primary and secondary syphilis do not appear to have changed in recent years.

In the first part of this study we reviewed the epidemiology of primary and secondary syphilis during a 20 year period.' In this section we consider the clinical features.

The clinical manifestations of early infectious syphilis have been recognised for centuries, ${ }^{2}$ and the detailed clinical descriptions all predate the penicillin era. ${ }^{34}$ There has been a recent suggestion that increasing herd immunity and the widespread use of antibiotics may have changed the clinical features of the disease, ${ }^{5}$ although a World Health Organisation scientific group report suggested that this was not the case. ${ }^{6}$ It is impossible to say which of these two views is correct, as there are no recent reviews of large numbers of patients.

In recent years the number of homosexual patients with early syphilis has increased. ${ }^{178}$ Despite this there are no studies comparing the clinical features in homosexual and heterosexual men. This study therefore aimed to review the clinical features of primary and secondary syphilis during a 20 year period and to compare them in homosexual men, heterosexual men, and women.

\section{Patients and methods}

We reviewed retrospectively the notes of all patients with primary and secondary syphilis who attended the department of genitourinary medicine at the Middlesex Hospital in 1965-84.' For patients with

Address for reprints: Dr A Mindel, James Pringle House, Middlesex Hospital, London W1N 8AA

Accepted for publication 25 June 1988 primary syphilis we recorded information about the site and number of any chancres and about associated lymphadenopathy. For those with secondary syphilis we recorded information about the history of chancres, the presence of skin rashes, condylomata, mucous patches, lymphadenopathy, fever, malaise, alopecia, and any rare clinical manifestation. We compared the clinical features in men with those in women and in heterosexual men with those in homosexual men.

The statistical test used was the $\chi^{2}$ test.

\section{Results}

We analysed the notes of 946 patients with primary and 854 with secondary syphilis.

Table 1 Sites of primary chancres comparing homosexual men, heterosexual men, and women (figures are numbers (percentages) of patients) (note that some patients had lesions at more than one site)

\begin{tabular}{llll}
\hline Site & $\begin{array}{l}\text { Heterosexual } \\
\text { men } \\
(n=184)^{*}\end{array}$ & $\begin{array}{l}\text { Homosexual } \\
\text { men } \\
(n=728)^{*}\end{array}$ & $\begin{array}{l}\text { Women } \\
(n=29) \dagger\end{array}$ \\
\hline Genital & $182(99)$ & $467(64)$ & $28(97)$ \\
Oral & 0 & $10(1)$ & $1(3)$ \\
Anorectal & 0 & $249(34)$ & $2(7)$ \\
Other & $3(2)$ & $8(1)$ & 0 \\
\hline
\end{tabular}

* Excluding four men whose sexual orientation was not known. †Excluding one woman for whom site was not known. IIncluding scrotum, natal cleft, and anterior chest wall. Comparing heterosexual with homosexual men at all four sites, $p<$ 0.001 . Difference between men (all) and women not significant. 
Table 2 Lymphadenopathy associated with chancres at various anatomical sites (figures are numbers (percentages) of patients)

\begin{tabular}{lccl}
\hline & Genital & Anorectal & Oral \\
\hline Heterosexual men & $148 / 178(83)$ & 0 & 0 \\
Homosexual men & $316 / 418(76)$ & $104 / 206(51)$ & $4 / 8(50)$ \\
Women & $17 / 25(68)$ & $1 / 1(100)$ & $0 / 1(0)$ \\
\hline
\end{tabular}

Comparing anorectal with genital sites in homosexual men, $\mathrm{p}<$ 0.01 .

\section{PRIMARY SYPHILIS}

Table 1 shows the sites of primary chancres. In men the commonest site affected was the penis. Of the 184 heterosexual men, $182(99 \%)$ had chancres on the penis compared with $467 / 728(64 \%)$ of homosexual men ( $p<0.0001)$. Of the 728 homosexual men, 249 $(34 \%)$ had chancres in the perianal or anal area. Chancres at sites other than genital or anorectal areas were uncommon. Of 642 men with penile chancres, most $(225(35 \%))$ were affected on the coronal sulcus, followed by the glans $(186,29 \%)$, the shaft $(141,22 \%)$, the prepuce $(123,19 \%)$, the frenulum $(66,10 \%)$, and the urinary meatus $(9,1 \%)$. In the remaining seven men the penile site was not known. Of the 649 men with genital chancres, $239(37 \%)$ had multiple lesions compared with $43 / 249(17 \%)$ with perianal chancres ( $p<0.0005)$. Of the 29 women with genital chancres, $22(76 \%)$ were affected on the vulva or vagina and six $(21 \%)$ on the cervix.

Table 2 shows that lymphadenopathy was more often associated with genital chancres than with those at other sites. For example, in homosexual men 316/ $418(83 \%)$ of the genital chancres had enlarged draining lymph nodes, compared with only 104/206 $(51 \%)$ of those at the perianal site.

Table 3 Clinical features of secondary syphilis comparing homosexual men, heterosexual men, and women (figures are numbers (percentages) of patients)

\begin{tabular}{|c|c|c|c|}
\hline & $\begin{array}{l}\text { Heterosexual } \\
\text { men }\end{array}$ & $\begin{array}{l}\text { Homosexual } \\
\text { men }\end{array}$ & Women \\
\hline $\begin{array}{l}\text { History of chancre } \\
\text { Chancre still present } \\
\text { Rash } \\
\text { Lymphadenopathy } \\
\text { Mucus patches }\end{array}$ & $\begin{array}{l}24 / 71(34) \\
25 / 74(34) \\
72 / 74(97) \\
56 / 72(78)\end{array}$ & $\begin{array}{l}159 / 692(23) \\
198 / 710(28) \\
654 / 700(93) \\
407 / 653(62)\end{array}$ & $\begin{array}{l}7 / 57(12) \\
10 / 57(18) \\
49 / 56(88) \\
27 / 55(49)\end{array}$ \\
\hline $\begin{array}{l}\text { Genital } \\
\text { Oral } \\
\text { Fever } \\
\text { Malaise } \\
\text { Condylomata lata }\end{array}$ & $\begin{array}{c}4 / 72(6) \\
16 / 73(22) \\
4 / 72(6) \\
10 / 73(14)\end{array}$ & $\begin{array}{c}27 / 700(4) \\
112 / 688(16) \\
38 / 692(6) \\
89 / 700(13)\end{array}$ & $\begin{array}{c}4 / 58(7) \\
11 / 57(19) \\
3 / 58(5) \\
7 / 58(12)\end{array}$ \\
\hline $\begin{array}{l}\text { Genital } \\
\text { Perianal } \\
\text { Alopecia }\end{array}$ & $\begin{array}{l}3 / 73(4) \\
7 / 73(10) \\
5 / 72(7)\end{array}$ & $\begin{array}{c}29 / 692(4) \\
104 / 685(15) \\
24 / 695(4)\end{array}$ & $\begin{array}{l}5 / 56(9) \\
5 / 57(9) \\
3 / 57(5)\end{array}$ \\
\hline
\end{tabular}

Comparing heterosexual with homosexual men, history of chancre $p$ $<0.05$, lymphadenopathy $\mathrm{p}<0.005$.

Comparing men with women, chancre still present $p<0.05$, lymphadenopathy $\mathrm{p}<0.03$.
Table 4 Distribution of rashes in secondary syphilis comparing homosexual men, heterosexual men, and women (figures are numbers (percentages) of patients)

\begin{tabular}{llll}
\hline Site & $\begin{array}{l}\text { Heterosexual } \\
\text { men }\end{array}$ & $\begin{array}{l}\text { Homosexual } \\
\text { men }\end{array}$ & Women \\
\hline Trunk & $476 / 664(71)$ & $57 / 73(78)$ & $38 / 51(75)$ \\
Back & $176 / 642(27)$ & $23 / 71(32)$ & $13 / 51(26)$ \\
Face & $116 / 652(18)$ & $14 / 71(20)$ & $17 / 51(33)$ \\
Arms & $305 / 650(47)$ & $38 / 72(53)$ & $25 / 50(50)$ \\
Legs & $230 / 646(36)$ & $28 / 71(39)$ & $17 / 51(33)$ \\
Palms & $278 / 654(43)$ & $36 / 70(51)$ & $32 / 51(63)$ \\
Soles & $289 / 653(44)$ & $28 / 70(40)$ & $20 / 50(40)$ \\
Genitalia & $238 / 658(36)$ & $22 / 70(31)$ & $5 / 31(16)$ \\
\hline
\end{tabular}

Comparing face, palms, and genitalia of all men with women, $\mathrm{p}<$ 0.005 .

\section{SECONDARY SYPHILIS}

Table 3 shows the common clinical features of secondary syphilis in heterosexual men, homosexual men, and women. The clinical features of the three groups were very similar, with most patients having a rash and lymphadenopathy, and all the other manifestations occurring in a few patients. Some significant differences were found, however, between heterosexual and homosexual men and between men and women. More heterosexual men $(24 / 71,34 \%)$ had histories of chancres than homosexual men $(159 / 629,23 \%)(p<$ 0.05 ) and lymphadenopathy was more common in the heterosexual men $(56 / 72,78 \%)$ than homosexual men $(407 / 653,62 \%)(p<0.005)$. More men $(463 / 725$, $64 \%)$ than women $(27 / 55,49 \%)(p<0.03)$ had lymphadenopathy, and chancres were still present at the time of examination in more men $(223 / 784,28 \%)$ than women $(10 / 57,18 \%)(p<0.05)$.

The notes of 763 patients contained a clinical description of their rashes. They were described as macular in $301(40 \%)$, maculopapular in $301(40 \%)$, and papular in $78(10 \%)$. The remaining $83(11 \%)$ had a variety of descriptions including squamous, pustular, and circinate. No significant differences in the descriptions of the rashes were seen between homosexual and heterosexual men or between men and women. Table 4 shows the distribution of the rashes.

Table 5 Rare manifestations of secondary syphilis in 854 patients

\begin{tabular}{lr}
\hline & No $(\%)$ patients \\
\hline Hepatitis & $4(0 \cdot 5)$ \\
Hepatomegaly (no evidence of hepatitis) & $3(0 \cdot 4)$ \\
Meningitis & $6(0 \cdot 7)$ \\
Headaches (no evidence of meningitis) & $17(2 \cdot 0)$ \\
Peripheral neuropathy & $2(0 \cdot 2)$ \\
Perceptive deafness & $4(0 \cdot 5)$ \\
Splenomegaly & $5(0 \cdot 6)$ \\
Periostitis & $2(0 \cdot 2)$ \\
Arthritis/arthralgia & $17(2 \cdot 0)$ \\
Iridocyclitis & $12(1 \cdot 4)$ \\
\hline
\end{tabular}


The commonest site for rashes was on the trunk. Significantly $(\mathrm{p}<0.005)$ more women than men had rashes on the palms of the hands $(32 / 51(63 \%) v 314 /$ $724(43 \%))$ and the face (17/51 (33\%) $v 130 / 723$ $(18 \%))$, whereas significantly $(p<0.005)$ more men $(260 / 728(36 \%))$ than women $(5 / 31,16 \%)$ had rashes on the genitalia. Homosexual and heterosexual men had no significant differences in the distribution of their rashes.

Table 5 shows the unusual manifestations of secondary syphilis, which were all extremely uncommon.

\section{Discussion}

The main difference in clinical features of primary syphilis between homosexual and heterosexual men was the considerable preponderance of anal chancres in homosexual men. Similar observations have been made previously. ${ }^{910}$ Anal chancres are often recognised when a patient presents to a sexually transmitted disease clinic, but misdiagnoses may occur if patients present to other agencies. ${ }^{\text {11 }}$

Extragenital chancres, other than those in the anal area, were extremely uncommon ( $2 \%$ of the total). This contrasts with the situation before the penicillin era, when extragenital chancres were apparently more common. In 1914-47 at the Johns Hopkin's Hospital 160 extragenital chancres $(7 \%$ of the total) were diagnosed. ${ }^{12}$ Only seven of these were from the anal area, and many of the remainder were thought to have been acquired non-sexually (through professional accidents by doctors, trauma, or nursing infected babies). Non-sexual transmission of syphilis would seem to be extremely uncommon in the modern era.

What of secondary syphilis? The clinical features appear to be very similar to those described in earlier studies, ${ }^{341314}$ and there appears to be little evidence that the clinical features have changed substantially in modern times.

Very few of our patients presented with the unusual manifestations of secondary syphilis (hepatitis, splenomegaly, neurological problems, iritis or periostitis). Hepatitis was diagnosed in only four (0.5\%) patients with secondary syphilis, which was not very different from the $0.2 \%(80 / 33825)$ found by Hahn in his review of the Johns Hopkins case material. ${ }^{15}$ Some debate still occurs as to whether syphilitic hepatitis occurs at all. The pathological features are not specific, ${ }^{16}$ and many of the case reports have not excluded other causes, including hepatitis A or B, cytomegalovirus, Epstein-Barr virus, or hepatitis nonA or non-B. ${ }^{17-19}$

The neurological problems associated with secondary syphilis are of some interest and, although exceptionally uncommon, they may pose difficulties with diagnosis. An additional concern is the recent observation that infection with HIV may make the neurological problems associated with secondary syphilis more "malignant and protracted". ${ }^{20-22}$

In conclusion, our study suggests that the clinical features of early syphilis have not changed substantially since the era before penicillin.

\section{References}

1 Mindel A, Tovey SJ, Williams P. Primary and secondary syphilis, 20 years' experience. 1. Epidemiology. Genitourin Med 1987;63:361-4.

2 Hunter J. Treatise on the venereal disease. 2nd ed. London: G Nicoll, 1788.

3 Stokes JH, Beerman H, Ingraham NR. Modern clinical syphilology. 3rd ed. Philadelphia: Saunders, 1944.

4 Kampmeier RH. Essentials of syphilology. Oxford: Blackwell Scientific, 1944.

5 Knox JM. Syphilis the change in clinical manifestations. In: Catterall RD, Nicol CS, eds. Sexually transmitted diseases. London: Academic Press, 1976:207-9.

6 World Health Organisation. Treponemal infections. WHO Tech Rep Ser 1982: No 674.

7 British Co-Operative Clinical Group. Homosexuality and venereal diseases in the United Kingdom. British Journal of Venereal Diseases 1973;49:329-34.

8 British Co-Operative Clinical Group. Homosexuality and venereal disease in the United Kingdom. British Journal of Venereal Diseases 1980;56:6-11.

9 Waugh MA. Studies on the recent epidemiology of early syphilis in West London. British Journal of Venereal Diseases 1972;48: 534-40.

10 Willcox RR. Changing patterns of treponemal disease. British Journal of Venereal Diseases 1974;50:169-78.

11 Drusin LM, Homan WP, Dineen P. The role of surgery in primary syphilis of the anus. Ann Surg 1976;184:65-7.

12 Tucker HA, Mulherin JL. Extragenital chancres: a survey of 219 cases. American Journal of Syphilis, Gonorrhea and Venereal Diseases 1948;32:345-64.

13 Lambkin FJ. The primary lesions and early secondary symptoms of syphilis as seen in the male. In: Power D, Murphy JK, eds. $A$ system of syphilis. Vol 1. Oxford: Oxford University Press, 1914:173-221.

14 Shillitoe A. The primary lesions and early secondary symptoms as seen in the female. In: Power D, Murphy JK, eds. A system of syphilis. Vol 1. Oxford: Oxford Medical Publications, 1914: 225-80.

15 Hahn RD. Syphilis of the liver. American Journal of Syphilis, Gonorrhoea and Venereal Diseases 1943;27:529-62.

16 Anonymous. Secondary syphilis and hepatitis. $\mathrm{Br} M e d \mathrm{~J}$ 1975;i:112.

17 Feher J, Somogyi T, Timmer M, Jozsa L. Early syphilitic hepatitis. Lancet 1975;ii:896-9.

18 Parker JDJ. Uncommon complications of early syphilis, hepatitis, periostitis, iritis with papillitis, and meningitis. British Journal of Venereal Diseases 1972;48:32-6.

19 Lee RV, Thornton GF, Corn HO. Liver disease associated with secondary syphilis. N Engl J Med 1971;284:1423-5.

20 Johns DR, Tierney M, Felsenstein D. Alteration in the natural history of neurosyphilis by concurrent infection with the human immunodeficiency virus. $N$ Engl $J$ Med 1987;316: 1569-72.

21 Berry CD, Houton TM, Collier AC, Lukehart SA. Neurologic relapse after benzathine penicillin therapy for secondary syphilis in a patient with HIV infection. $N$ Engl $J$ Med 1987;316:1587-9.

22 Tramont EC. Syphilis in the AIDS era. $N$ Engl $J$ Med 1987;316:1600-1. 